\title{
Incivilismo e a aliança entre neoliberalismo e mídia
}

\section{Uncivilism and the alliance between neoliberalism and media}

\section{Incivilismo y la alianza entre el neoliberalismo y los medios}

Jadson Maia

Universidade Federal do Rio Grande do Norte (Brasil)

SODRÉ, Muniz. A sociedade incivil: mídia, iliberalismo e finanças. Petrópolis: Editora Vozes, 2021.

Muniz Sodré (1942) é professor-titular da Universidade Federal do Rio de Janeiro (UFRJ). Seus livros versam sobre comunicação e sociedade, mas corroboram também para o desenvolvimento das investigações do campo comunicacional. Por exemplo, O monopólio da fala (1977) é uma obra que se debruça sobre o impacto da televisão na linguagem e na produção do indivíduo na realidade brasileira, enquanto Antropológica do espelho (2002) atualiza o fenômeno comunicativo com a rede e a nova ordem tecnoeconômica.

A sociedade incivil, de 2021, apreende a relação substancial entre o neoliberalismo e a comunicação eletrônica com fôlego transdisciplinar, que marca o pensamento do autor. O livro está organizado, além do prólogo, em três capítulos: Parte I - Causas, Parte II -Efeitos e, por fim, Parte III - Colaterais. O argumento da obra é que a atualidade é caracterizada pela derrocada do civilismo, entendido pelo autor como a "[...] negociação pública das diferenças, cooperação, solidariedade, discernimento crítico e amizade cívica ou phylia [...]" (SODRÉ, 2021, p. 9), como consequência das mutações econômicas la especulação financeira de ações e títulos em detrimento da produção tradicional) que têm como infraestrutura a internet. $O$ conceito de sociedade incivil, proposto com Raquel Paiva, é assim sintetizado:

Um ordenamento humano regido globalmente por tecnologias da comunicação, solidárias à transformação no modo de acumulação do capital, à desestabilização das formas clássicas de representação do mundo, mas também ambiguamente atravessadas pela incitação generalizada à reinvenção institucional (SODRÉ, 2021, p. 23). 
A citação expõe como a informação e a comunicação em rede são instrumentos que ampliam o controle dos indivíduos pelo regime neoliberal. Assim, a promessa de pluralidade e inclusão suscitada pela rede ainda no fim do século XX, sobretudo na intelectualidade, não se concretizou no seu amadurecimento. $\bigcirc$ incivilismo de nossa sociedade hiperconectada, ao contrário, corrói a própria democracia, vide a chegada ao poder do ultraconservadorismo neoliberal pelo globo. Isso porque a potência democrática da rede foi tomada pelas gigantes digitais (Google, Amazon, Facebook, entre outras) à medida que a "sociabilidade de plataforma" e a troca frenética de mensagens (responsividade), atributos que the são constitutivos, trabalham mais pela "ausência de diálogo" e "retrocesso discursivo" do que pela construção de verdade consensual e vinculativa que estabiliza a sociedade. Não é à toa que Sodré recupera a discussão de $\bigcirc$ monopólio da fala para reafirmar que o sujeito segue tendo sua autonomia sequestrada pelos meios, seja TV ou Internet. Agora, porém, isso ocorre de maneira sofisticada através de um ambiente estimulante, regido por algoritmos, no qual os dados dos usuários são extraídos para comercialização.

A Parte I - Causas, traça a relação do capitalismo financeiro com a 2 tecnologia eletrônica e mídia. Para entender essa indissociabilidade, é preciso distinguir comunicação de comunicação funcional, a materialidade do fenômeno no seio social, a "[...] mídia corporativa, publicidade, marketing, redes digitais e produção imaterial" (SODRÉ, 2021, p. 43). A década de 1970 sinalizou a crescente desregulamentação do mercado financeiro frente ao Estado e a especulação rentável em torno de papéis pelo capitalismo. "No centro desse processo se coloca o capital fictício; isto é, a lógica de apropriação de valor por meio de finanças (títulos de crédito, ações) em detrimento da produção [...]", argumenta Sodré (2021, p. 72). Apesar de ter sido explicado por Karl Marx, ainda no século XIX, a financeirização e a crise financeira são as novidades da contemporaneidade apontadas por Sodré. $\bigcirc$ processo acentuou-se e há hoje uma retirada considerável de capital do setor produtivo para a aplicação financeira e rentismo.

A maximização do lucro capitalista da financeirização ignorou, por exemplo, o aumento exponencial de mortes pela pandemia do novo coronavírus nos EUA e as ações de grandes empresas registravam crescimento. Para arrematar o argumento de conjugação entre capitalismo financeiro e mídia, Sodré articula a mudança de sociedade disciplinar para sociedade 
de controle. As noções, de Foucault e Deleuze respectivamente, explicam a transformação de um cenário amplo de governança social, no qual o controle das condutas se dá cada vez mais através de técnicas brandas e midiatizadas operadas mais por empresas do que pelo próprio Estado, bem como a instrumentalização dos dados dos usuários. $\bigcirc$ conluio efetua, portanto, uma modificação civilizacional profunda em que deixamos para trás a sociedade civil, como cultura da antiga democracia liberal, e passamos para a sociedade incivil, uma tecnocracia orquestrada pelo capitalismo financeiro e inimiga das ideologias do Estado de bem-estar social.

A parte II - Efeitos, percorre os elementos que forjam a sociedade incivil e seus indivíduos. Como primeiro elemento está o assédio das instituições sociais pelos interesses das organizações privadas. Sodré recupera a distinção entre instituição e organização baseando-se em Sartre. A primeira tem dinâmica contraditória, pois é "coisa inerte" mas sua prática pode ser transformadora, já a segunda regula as finalidades objetivas para promover a produção de bens e serviços. Podemos, portanto, circunscrever instituição como aquilo que maximiza o comum e os vínculos sociais e a organização o que maximiza a produção e o lucro de determinado grupo. Nesta diferenciação, Sodré situa a mídia, "mainstream media" ou "[...] mídia corporativa", como uma organização. Aqui entra em cena o segundo elemento que galvaniza a sociedade incivil, a mídia como dispositivo sociotécnico e de subjetivação dos indivíduos ultrapassando as mediações políticas tradicionais, como Lei e Estado. A mídia é uma instância de dessubjetivação do sujeito para remodelá-lo sob a prescrição do poder neoliberal. Dispositivo tal como definiu Agamben, como aquilo que pode controlar, orientar, incitar em certa direção, lembra Sodré (202 1). Um exemplo dessa mentalidade é a concorrência entre indivíduos que se pensam soberanos, donos do seu próprio tempo, insensíveis às desigualdades sociais. Apenas a reativação da institucionalidade civil pode solapar o incivilismo.

Por fim, a Parte III - Colaterais, recolhe acontecimentos do desenvolvimento tecnológico neoliberal que aproximam autômatos ou robôs e "sujeitos de ódio". A sessão traz uma série de estudos sobre identidade para que o autor possa inserir sua abordagem sobre o tema. $\bigcirc$ que se pretende é a transparência total do indivíduo, com a análise massiva de dados para extrair correlações (data analytics) e gerar "performances insuspeitas", em que a midiatização é "[...] fenômeno de autoconstrução de identidades favorecidas por organizações de mercado e facilitada por dispositivos tecnológicos" (SODRÉ, 2021, p. 
215). Métodos de aprendizagem automáticos (inteligência artificial) consolidam capacidade de tomada de decisão e intuição em robôs. $\bigcirc$ fato aponta não só para a substituição de uma vasta gama de profissionais e a redução de vagas e renda do trabalho humano, mas para um novo estatuto do robô em nossa sociedade. É na desestabilização de identidades pessoais e institucionais da sociedade civil que o ódio surge como forma social e afeto vinculativo dos protofascismos atuais dirigido criminosamente às minorias.

Em última análise, Muniz Sodré segue problematizando o regime de poder que investe os meios de comunicação e provoca mudanças antropológicas radicais. Subjetividade, valores sociais e instituições são reconfigurados com a atual inflexão econômica e midiática. Não obstante, "A sociedade incivil" oferece ao leitor uma visão ampliada da comunicação, que discute epistemologia, teoria, atualizações metodológicas necessárias e os desafios do pesquisador num contexto de transformação contínua. No âmbito da educação, o presente livro sugere contraponto às tecnologias digitais, revelando seus interesses escusos. Se elas permitiram que alunos e professores continuassem suas atividades a distância, em meio a pandemia de Covid-19, elas também acrescentaram precariedade ao trabalho docente. A gravação e reprodução continuada das aulas sem qualquer ganho adicional e, por conseguinte, o enxugamento das equipes já são aspectos da realidade de digitalização da educação.

\section{Referências}

SODRÉ, Muniz. O monopólio da fala: função e linguagem da televisão no Brasil. Petrópolis: Editora Vozes, 1977.

SODRÉ, Muniz. Antropológica do espelho: uma teoria da comunicação linear e em rede. Petrópolis: Editora Vozes, 2002. 
Dr. Jadson Maia

Universidade Federal do Rio Grande do Norte (Brasil)

Programa de Pós-graduação em Ciências Sociais Grupo de Pesquisa: Marginália - Grupo de Estudos Transdisciplinares em

Comunicação e Cultura Orcid id: https: / / orcid.org/0000-0003-0 148-3975

E-mail: jadsonmaia@ufrn.edu.br

Recebido 15 nov. 2021

Aceito 3 dez. 2021 